\title{
SEX RATIO AND AGE STRUCTURE PATTERNS OF ASIAN ELEPHANTS FROM PENINSULAR MALAYSIA REVEALED BY NON-INVASIVE SURVEYS
}

\author{
K. V. Karuppannan ${ }^{1,2}$, K. A. Mohamed ${ }^{1}$, M. F. A. Abdul-Razak', N. F. D. Ahmad-Tahir' ${ }^{1}$, N. A. Mohd-Naim¹, C. \\ Keliang ${ }^{1}$, S. Yaakop ${ }^{2}$, J. E Maldonado ${ }^{3}$ and B. M. Md-Zain ${ }^{2}$ \\ ${ }^{1}$ Department of Wildlife and National Parks (DWNP), KM 10 Jalan Cheras, 56100 Kuala Lumpur, Malaysia. \\ ${ }^{2}$ Department of Biological Sciences and Biotechnology, Faculty of Science and Technology, 43600 Universiti \\ Kebangsaan Malaysia, Bangi, Selangor, Malaysia. \\ ${ }^{3}$ Center for Conservation Genomics, Smithsonian Conservation Biology Institute, Washington DC, United States of \\ America. \\ Corresponding author's email: abgbadd@ukm.edu.my
}

\begin{abstract}
An effective conservation and management plan of Asian elephants in Peninsular Malaysia relies on understanding the population biology and ecology of the species. Since molecular genetic tools have been developed and widely used for elephant conservation, the Malaysian Department of Wildlife and National Parks (DWNP) aimed to obtain estimates of population size, individual identification and sex specific gene flow among elephant populations in Taman Negara National Parks (TNNP) in line with one of the long-term goals in the National Elephant Conservation Action Plan (NECAP). In this study, we apply non-invasive molecular techniques to sex Asian elephant faecal and we combine it with measurement of bolus dimensions to get reliable baseline information on sex ratio as well their age structure in TNNP, Peninsular Malaysia populations. Two Y chromosome specific fragments (SRY1 and AMELY2) and one X chromosome specific fragment (PLP1) were used to determine the sex of the elephants that were detected during our surveys in the TNNP study locations. A total of 217 fresh faecal samples from 31 sampling sites and measurements of each bolus circumference were analysed. Faecal samples from 10 elephant individuals of known sex from the National Elephant Conservation Centre (NECC), Kuala Gandah were included as controls. We identified 86 males and 131 females in TNNP via molecular sexing approach. In addition, to estimating the sex ratio in TNNP, we also categorized the different sexes into three different age classes by measuring mean of bolus circumference. Neonates/juveniles (Class 1) and sub-adults (Class 2) were composed of approximately an even number of males and females. However, our results of sexing, boli from adults (Class 3 ) revealed a lower number of males with 40 individuals compared to 84 females. This female biased sex ratio in adults could be due to poaching pressure on male adults around the study areas. Alternatively, we could have failed to detect more males because bulls are known to be more solitary and roam further in deeper forest areas away from their matriarchal herds and far from our sampling locations during our surveys. Despite these potential issues with detection of bulls, this study provided reliable information on the sex ratio pattern and age structure of free roaming elephant populations in TNNP. This information provides valuable scientific based management tools for DWNP as well policy makers in order to make decisions for future elephant conservation management plans in TNNP.
\end{abstract}

Keywords: Asian elephant, XY chromosome-specific markers, bolus circumference, age structure, poaching.

https://doi.org/10.36899/JAPS.2020.6.0163

Published online August 03,2020

\section{INTRODUCTION}

In Peninsular Malaysia, Asian elephants (Elephas maximus) are widely distributed in the states of Johor, Pahang, Kelantan, Terengganu, Kedah and Perak (IUCN, 2017). Elephants in Peninsular Malaysia are categorized as a protected species under the Wildlife Conservation Act of 2010 (Act 716) and as "Endangered" in the International Union for Conservation of Nature (IUCN) Red List of Threatened Species (Choudhury et al., 2008). A better understanding of their population biology is needed to guide management decisions for effective conservation strategies of this endangered species (DWNP Annual Report, 2015; IUCN, 2017;
Salman et al., 2011).

The Asian elephant is listed in the Convention on International Trade in Endangered Species of Wild Fauna and Flora (CITES) under Appendix I which covers most endangered wildlife and plants (CITES, 2017). The three main prioritized conservation actions listed for Asian elephants were to: 1) protect and manage elephant habitat by connecting secured corridors, 2) reduce human - elephant conflict by mitigating community based crop guarding actions and 3) enhance law enforcement to reduce poaching in elephant habitats (DWNP, 2013). In addition, research efforts that are focused on the continuous monitoring of the population size and their trends are urgently needed as part of an adaptive 
management action in conserving Asian elephants (Asian Elephant Conservation Act, 1997; Fernando and Leimgruber, 2011).

In 2013, the National Elephant Conservation Action Plan (NECAP) was developed within the existing framework of the Malaysian Government for environmental and biodiversity conservation. Specifically, the National Policy on Biological Diversity and National Policy on the Environment set the underlining principles (DWNP, 2013), whilst the National Physical Plan laid out the spatial framework. The NECAP is a results-driven, adaptive action plan, founded on the commitment of the Malaysian government and its partners to save Peninsular Malaysia's elephants. Department of Wildlife and National Parks (DWNP) Peninsular Malaysia, as a management authority for wildlife, have faced great challenges in managing and conserving this precious species. Since the application of science and technology have been developed, DWNP decided to apply molecular genetics tools towards Asian elephant conservation in Peninsular Malaysia and obtain estimates of population size, individual identification as well sex specific gene flow. This will provide baseline information needed to make decisions regarding the long term management of the Malaysian Asian elephant population (Fernando et al., 2003; Hedges, 2012; Okello et al., 2008; Sripiboon, 2013; Vidya et al., 2005).

The key study area selected by DWNP was the Taman Negara National Parks (TNNP). This is the largest primary rainforest and is ideal for conducting genetic assessment of Asian elephant population as listed as one of the long term objective in NECAP. Non-invasive DNA based research was carried out to estimate levels of genetic variability and population sizes as well as to study their social organization and sex ratio in wild elephant populations in TNNP (DWNP, 2013). Previous studies had demonstrated that for molecular based studies (Zainudin et al., 2010; Aifat et al. 2016; Abdul-Latiff et al. 2017), non-invasive samples could provide reliable information compared to elephant blood (Elliza et al., 2015). This study focuses specifically on the determination of sex ratio among free ranging wild elephant individuals in TNNP by using molecular sexing approach. In addition, we also conducted age classification of all tested elephant individuals. The primary objective of this study was to better understand sex ratio composition amongst different elephant age groups which in turn will help us elucidate the fine scale demographic characteristics of the wild elephant populations in the TNNP.

\section{MATERIALS AND METHODS}

Sampling: Our study locations were in the Taman Negara National Park which covers some parts of
Pahang, Terengganu and Kelantan states. Plot sampling method (Borchers et al., 2002) was chosen and a total of 147 sampling plots sized $16 \mathrm{~km} 2$ were selected (Figure 1). Criteria in selecting these plots or hotspots were sites with high elephant food sources, saltlicks areas, shrubs, closed canopy, waterholes and animal trails where elephant faecal piles can be found reliably (Borchers et al., 2002; Salman et al., 2011). Faecal DNA-based sampling was carried out at all selected plots. Fresh or reasonably fresh faecal were collected along the targeted trails. Reasonably fresh is referred to one or two days old faecal piles (Ahlering et al., 2011a; Chakraborty et al 2014; Hedges and Lawson, 2006).

Total of nine sampling programs (NECAP $1^{\text {st }}$ to NECAP $9^{\text {th }}$ ) from 31 sampling sites were carried out between March 2016 and September 2017 (Table 1). We managed to collect two hundred and twenty three (223) fresh or reasonably fresh faecal samples throughout these programs. Collected fresh or reasonably fresh faecal samples were preserved in FTA cards (FTA Technology, 2011) and in customized tubes contain molecular grade absolute ethanol (99\%). The outer layer of faecal samples was swabbed or scabbed and preserved in both preservation methods and all samples were stored in room temperature. Measurement of each bolus circumference $(\mathrm{cm})$ was recorded together with Global Positioning System (GPS) coordinates of sampling sites by using Garmin GPSmap 62. Measurements only were taken after collecting required DNA samples to avoid contamination.

Laboratory analysis: Total of 217 out of 223 faecal samples were derived from different elephant individuals or having unique genotypes. The genotyping analysis were conducted by using microsatellite markers. These 217 selected samples were selected for molecular sexing analysis. In addition, positive control faecal samples from ten elephant individuals with combination of five females and five males from National Elephant Conservation Centre (NECC) were added. Positive control samples were used as reference during allele scoring and to avoid errors during finalising correct alleles.

All the samples preserved on FTA cards were chosen for extraction; while samples preserved in absolute ethanol were deposited in the DWNP Wildlife Biomaterial collection unit. DNA extractions were completed by using the QIAGEN DNeasy Blood \& Tissue Kit because cells can be lysed on FTA cards, avoiding DNA degradation (Abdul-Latiff et al., 2019). DNA extractions were conducted in a separate area away from the PCR room to avoid contamination from PCR products (Md-Zain et al., 2018). Negative controls, where sample without faecal material added to the extraction accompanied each set of extractions and were used to check for contamination (Md-Zain et al., 2010). Quantification of DNA was completed by using 
NanoDrop 2000 Spectrophotometer (Thermo Fisher Scientific 2010).

We used two short Y-specific fragments (SRY1 and AMELY2) with $71 \mathrm{bp}$ and $122 \mathrm{bp}$ and one longer Xspecific fragment (PLP1) with $191 \mathrm{bp}$. Primer SRY1 and PLP1 were fluorescently labelled with HEX, and AMELY2 was labelled with FAM (Ahlering et al., 2011b). Multiplex PCR Amplification with $20 \mu \mathrm{L}$ reaction consisted of $10 \mu \mathrm{L}$ PCR Master Mix, 2X (Promega, 2016), $2 \mu \mathrm{L}$ of ddh2O, $1 \mu \mathrm{L}$ each of $10 \mu \mathrm{M}$ primers, and $2 \mu \mathrm{L}$ of template DNA. Annealing temperatures ranged from $57^{\circ} \mathrm{C}$ to $59^{\circ} \mathrm{C}$. The amplification protocol consisted of 10 minutes initial denaturation at $95^{\circ} \mathrm{C}$, followed by 40 cycles of $30 \mathrm{sec}, 1$ min extension at $72^{\circ} \mathrm{C}$ and a final extension of $10 \mathrm{~min}$ at $72^{\circ} \mathrm{C}$.

Three replicates of PCR were conducted for all 217 samples. Negative controls with no DNA template added as well as positive controls from faecal samples of elephants of known sexes were also included in each set of PCR reactions. All un-purified PCR products from three replicates were sent to Apical Scientific Sdn. Bhd, a private laboratory for fragment analysis. FASTAformatted raw data from fragment analysis were analysed using GeneMapper® Software 5 (Life Technologies Corporation, 2012). Fragment analyses confirmed three peaks for males and one peak for females, as expected (Ahlering et al., 2011b).

Population Age Structure: Elephant dung bolus circumference measurements has capability to reveal information on the age composition of the group. Estimated age class of elephants were retrieved from intact dung bolus circumference measurement size and it was recorded in centimetres $(\mathrm{cm})$ by using a flexible plastic measuring tapes as shown in Figure 2 (Hedges et al., 2013; Moßbrucker et al., 2015). Three different age classes were assigned from mean bolus circumference (mbc) as described by Tyson et al. (2002):

$\mathrm{mbc} \leq 30 \mathrm{~cm}=$ neonates \& juveniles

$30 \mathrm{~cm}<\mathrm{mbc} \leq 42 \mathrm{~cm}=$ sub-adults

$\mathrm{mbc}>42 \mathrm{~cm}=$ adults

\section{RESULTS}

Elephant DNA was successfully amplified from all the 217 genotyped individuals from TNNP. The three molecular sexing markers showed 131 numbers of samples from females while remaining 86 samples from males. We detected the expected size of $71 \mathrm{bp}$ for the SRY1 locus. While primers that amplified the AMELY2 and PLP1 loci showed a 122 bp and 191 bp fragment respectively. All the 131 samples from females amplified a single peak for primer PLP1 while samples from males showed the three peaks of the expected size for each of the loci. These results were compared and confirmed with the fragment size pattern from the ten known positive control samples. All the tested samples were arranged based on nine sampling programs to check the sex ratio distribution among elephant population in TNNP as summarized in Figure 3. The outcome shows, higher number of female elephants were found throughout these studies except during 2nd and 9th sampling programs. More male elephants found during these two sampling programs which were conducted around $\mathrm{Sg}$ Tanum, $\mathrm{Sg}$ Masuk, Sg Lebir, Sg Relai, Sg Temau, Sg Ara, Sg Koh and Kg Pagi.

\section{Table 1. List of sampling sites.}

\begin{tabular}{clc}
\hline No & Sampling sites & Number of samples \\
\hline 1 & Sg Petang & 1 \\
2 & Kechau & 1 \\
3 & Gua Gajah & 4 \\
4 & Gua Pengingat & 7 \\
5 & Jenut Sg Yu & 6 \\
6 & Kg Pagi & 11 \\
7 & Sg Ara & 6 \\
8 & Sg Cacing & 23 \\
9 & Sg Cicir & 2 \\
10 & Sg Keniyam & 10 \\
11 & Sg Kepung & 1 \\
12 & Sg Ketil & 2 \\
13 & Sg Koh & 10 \\
14 & Sg Lebir & 12 \\
15 & Sg Masuk & 11 \\
16 & Sg Relai & 9 \\
17 & Sg Sat & 7 \\
18 & Sg Sepia & 16 \\
19 & Sg Tanum & 15 \\
20 & Sg Temau & 4 \\
21 & Sg Tembeling & 14 \\
22 & Sg Tenur & 1 \\
23 & Sg Terenggan & 23 \\
24 & Sg Wa & 4 \\
25 & Sg Yong & 1 \\
26 & Tasik Kenyir & 1 \\
27 & Sg Pertang & 5 \\
28 & Sg Mentut & 2 \\
29 & Sg Pak Chau & 4 \\
30 & Sg Perepek & 1 \\
31 & Aring 10 & 3 \\
\hline & TOTAL & \\
\hline & & 217 \\
\end{tabular}

The ranges of recorded bolus circumference measurement of both males and females were $20.0-58.2$ $\mathrm{cm}$ and $19.3-53.2 \mathrm{~cm}$ respectively as shown in Table 2 . There were 3 age classes of Asian elephants developed based on dung size (Tyson et al., 2002), which were Class 1: 0-5 years of neonates and juveniles; Class 2: 5 15 years of sub-adults and finally Class 3: older than 15 years of adults. A complete dataset on mean of bolus 
circumference (mbc) of each 217 samples was analysed to evaluate their age structure as shown in Table 3 and Figure 4. Outcome shows higher number of faecal samples was collected from adult elephant except for 6th and 7th sampling programs. This two sampling were carried out in Aring 10 and Sg Koh. These two locations were in deeper part of forest. In overall, the percentage of adult elephants in all the 31 sampling sites was above $50 \%$. In addition, the presence of sub-adult categories was second highest after adults. The elephant individuals from juvenile or neonates' groups were less than $10 \%$.

Table 2. Summary of minimum - maximum, mean \pm SD and median of bolus circumferences measurement $(\mathrm{cm})$ of each collected dung samples $(\mathrm{N})$ in TNNP

\begin{tabular}{ccccc}
\hline Sex & N & Min-Max & Mean \pm SD & Median \\
\hline Female & 131 & $19.3-53.2$ & $43.05 \pm 6.89$ & 44.2 \\
Male & 86 & $20.0-58.2$ & $40.40 \pm 9.23$ & 41.1 \\
\hline
\end{tabular}

Table 3. Age structure of Asian elephants in TNNP.

\begin{tabular}{cccccc}
\hline Mean of Bolus Circumference, $\mathbf{m b c}(\mathbf{c m})$ & Age Class & Age Group & Male & Female & Total \\
\hline$m b c \leq 30$ & Class 1 & neonate/juvenile & 11 & 4 & $\mathbf{1 5}$ \\
$30<\mathrm{mbc} \leq 42$ & Class 2 & sub-adults & 35 & 43 & $\mathbf{7 8}$ \\
$\mathrm{mbc}>42$ & Class 3 & adults & 40 & 84 & $\mathbf{1 2 4}$ \\
\hline
\end{tabular}

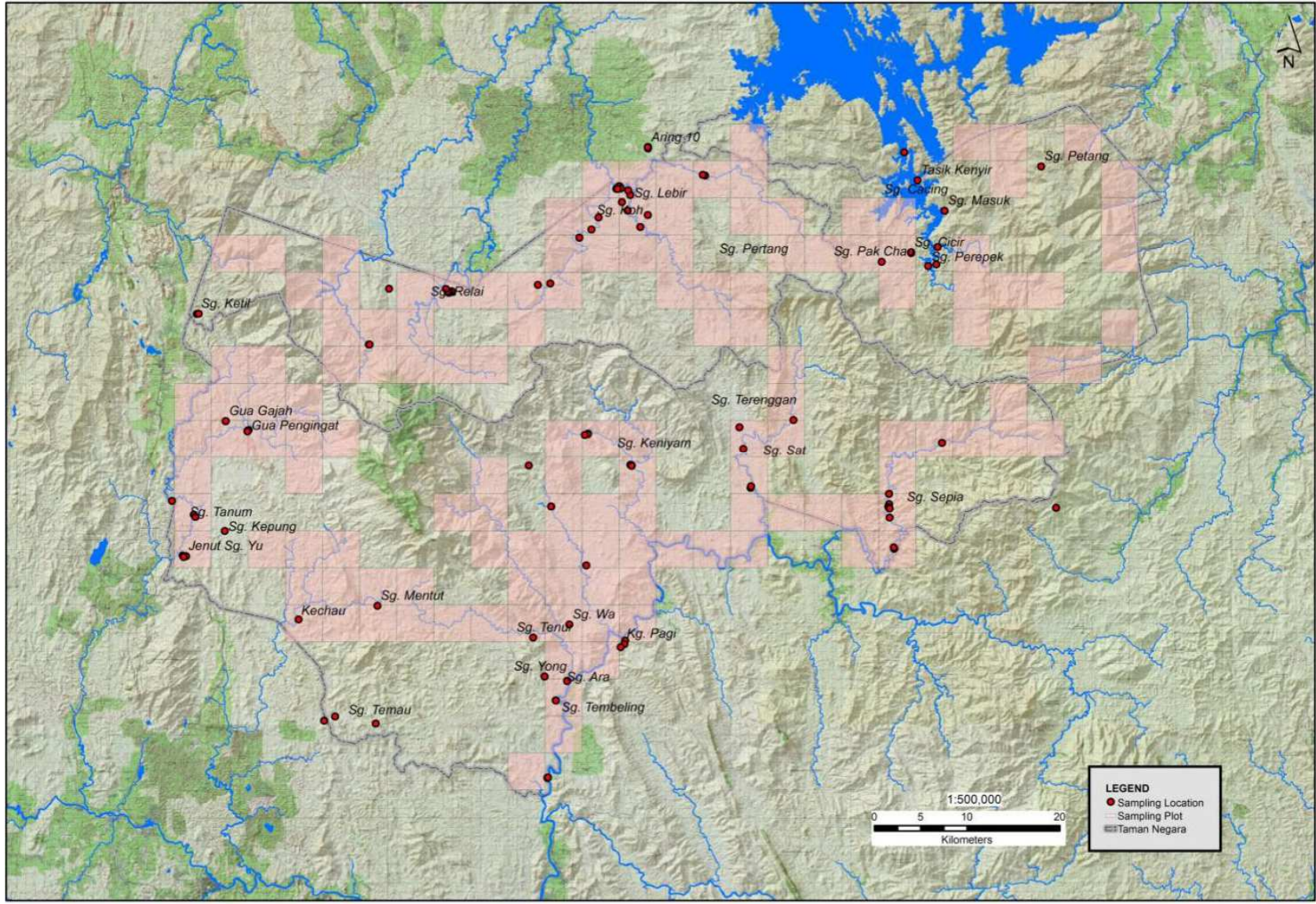

Figure 1. Selected sampling sites in Taman Negara National Park 


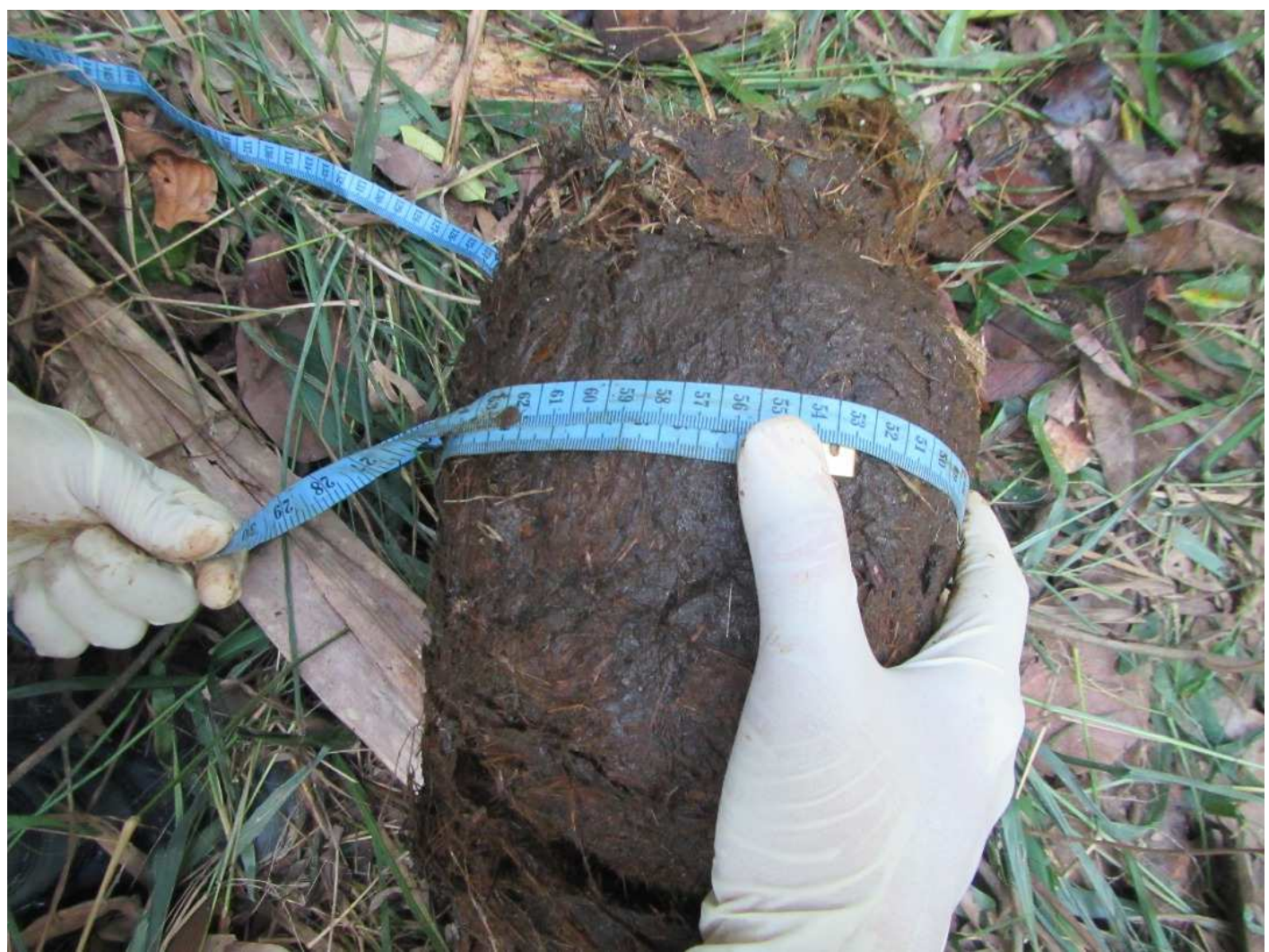

Figure 2. Measurement of boli circumference.

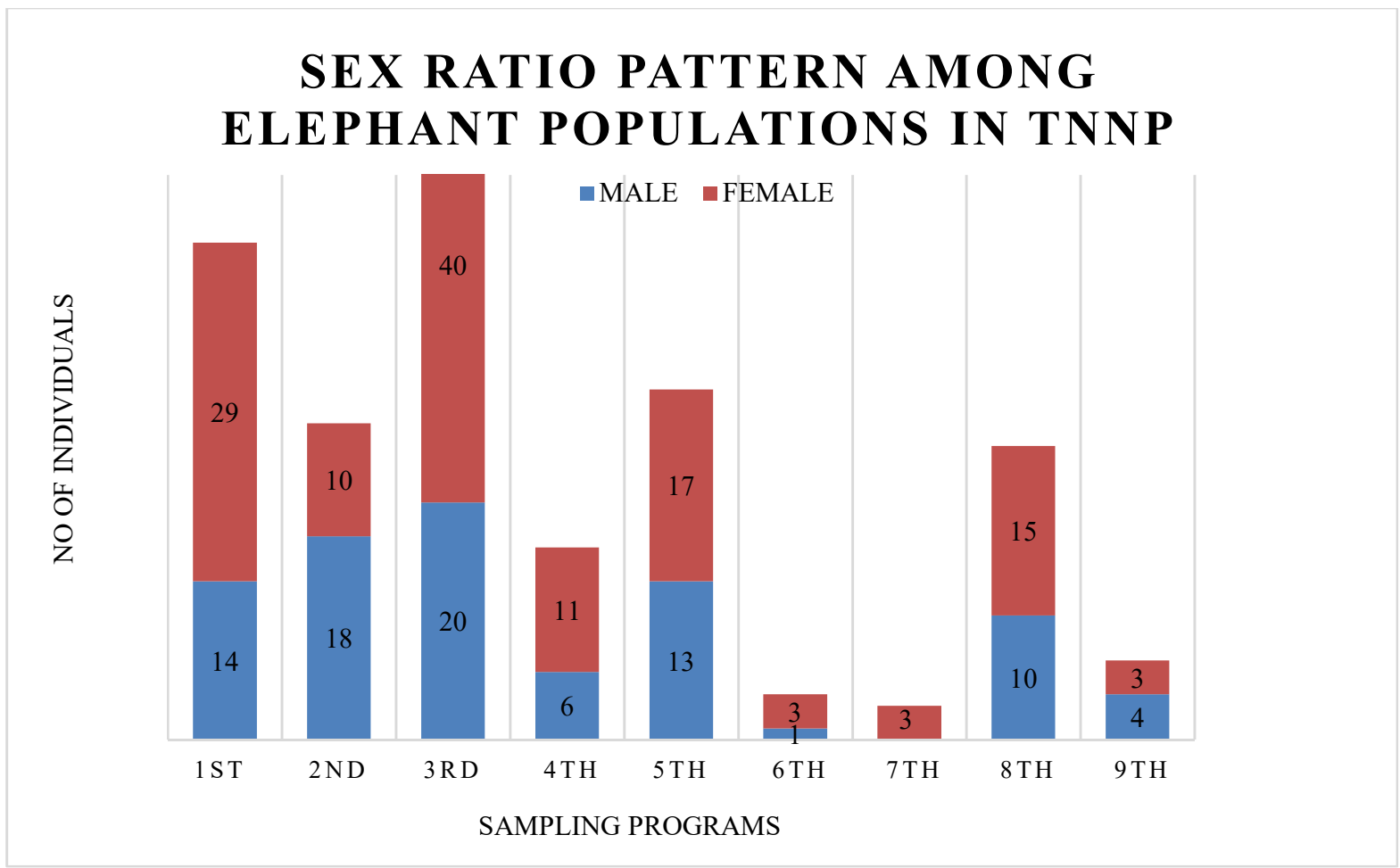

Figure 3. Sex ratio pattern of Asian elephants in TNNP. 


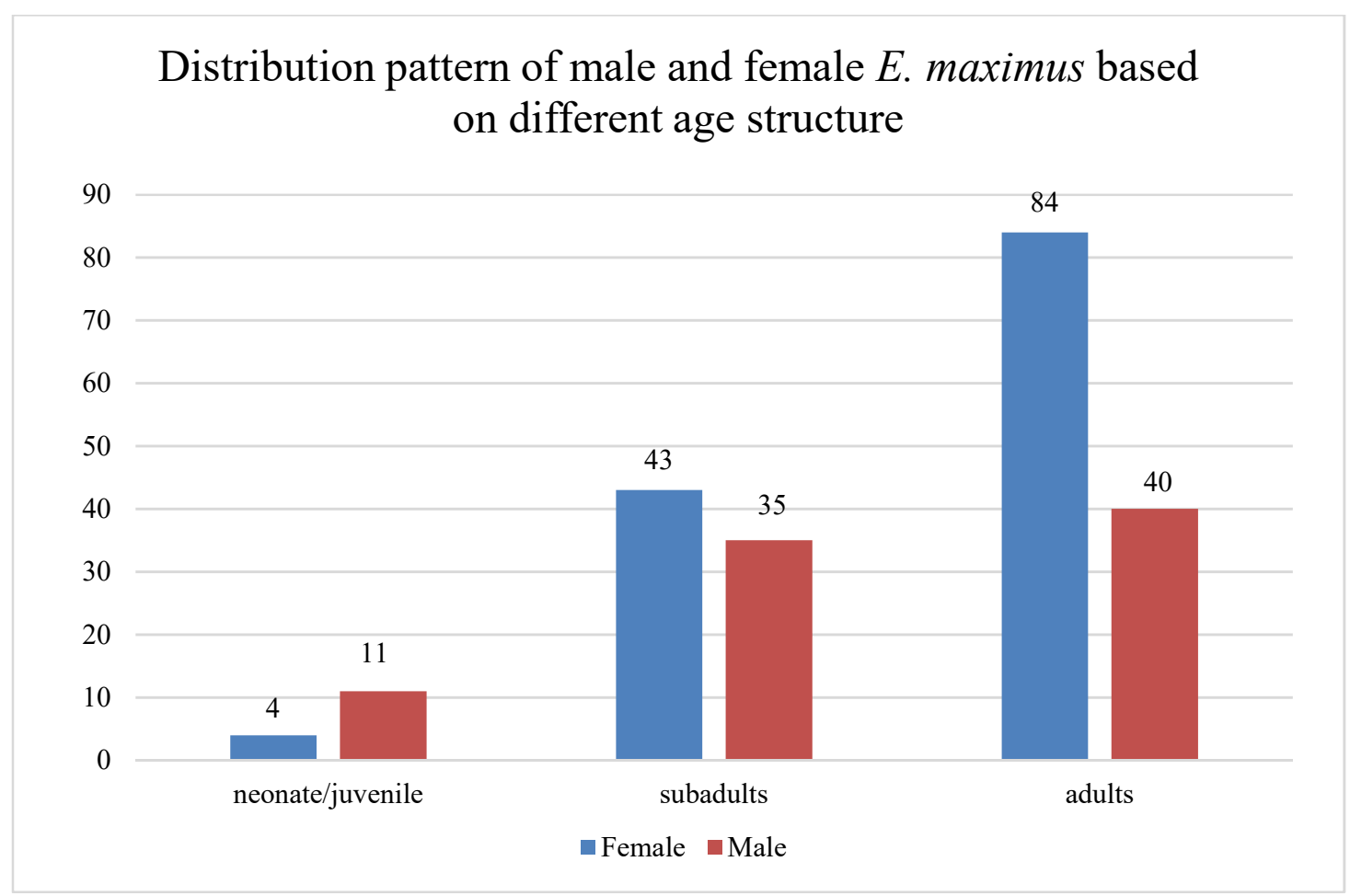

Figure 4. Distribution of females and males based different age class.

\section{DISCUSSION}

The molecular sexing analysis have identified $60 \%$ of females from total of 217 tested samples and remaining were from males. An average of allele scoring from three pairs of sexing markers were summarized this sex ratio among tested elephant populations. Comparisons with positive controls were minimized percentage of misinterpretation during allele scoring.

The outcome from DNA based sex determination together with the elephant dung bolus measurements contributed in their abundance estimation in TNNP (Moßbrucker et al., 2015). Male and female bolus circumferences were of similar in size as determined by the overall mean and median circumference of bolus of each sex. According to Kongrit and Siripunkaw (2017) and Vidya et al. (2003), the circumference of an Asian elephant bolus can indicate the sex of that individual and the normal accepted range of male bolus circumference is $17.33-58.33 \mathrm{~cm}$, while female bolus circumference ranges $19.67-53.50 \mathrm{~cm}$. Our recorded range of bolus circumference is concordant with this previous research conducted in Salakphra Wildlife Sanctuary, Kanchanaburi province Thailand (Kongrit and Siripunkaw, 2017)

Asian elephants are also slow reproducing and have long life spans. They are known to have a higher survival rates at an older age after the more risky postnatal years (Sukumar, 2003). Therefore, we expect larger number of adult elephants in natural populations compared to sub-adults either juveniles or young calves (Kumara et al., 2012; Moßbrucker et al., 2015). Our 217 samples had shown almost a balanced number of both sexes in juveniles and sub adults but the situation changed with a female biased ratio of more than $60 \%$ for adult elephants.

Our results suggest that many young males are detected compared to old bulls. In nature, elephants are born at equal sex ratios but unfortunately males suffer from increased mortality rates which explain the female biased ratios in older age groups found in many range countries (Easa and Balakrishnan, 1995; Katugaha et al., 1999; Sukumar, 2003; Williams et al., 2007). For example, in Sumai and Riau Jambi area at Bukit Tiga Puluh landscape in Indonesia had approximately twice as many adult females compared to adult males (Moßbrucker et al., 2015)

This low number of adult males in TNNP could be due to poaching aimed directly at ivory in male tusks. Poaching for ivory was also a threat in other elephant populations that has resulted in extremely skewed female ratios, thus affecting breeding rates (Nagulendran et al., 2016; Ripple et al., 2017). Our results call for DWNP to take urgent measures to tighten up enforcement activities in the TNNP to protect wild Asian elephant's particularly older bulls from poaching.

In addition to poaching activities, the low percentage of adult males detected during our surveys could also be compounded by the different movement habits of males and females. Our criteria for selecting our 
survey sites were the availability of adequate amounts of water and food resources. While both males and females prefer high water and food source areas for survival (Salman et al., 2011), male elephants tend to move further away from these desired areas compared to females. According to Magintan et al. (2016), during hydroelectric dam construction in Hulu Terengganu, Terengganu, Peninsular Malaysia, the movement patterns of GPS-collared male and female elephants were similar, but the home-range area of males was larger than that of females because the males roamed deeper into the forest. The bulls could have moved far from our targeted trails while we were conducting our sampling surveys. In the future, we recommend that a wider range of sampling plots be included to cover the possible roaming range of adult male elephants (Neupane et al., 2019; Wadey et al., 2018)

Application of molecular sexing coupled with field parameters like dung bolus circumference measurement demonstrates that pattern of female: male distribution with their age structure among wild free ranging Asian elephants. This will play an important role in developing a DNA profile database on free ranging Asian elephants in TNNP. This fingerprinting database will generate key elements for evidence-based conservation in line with the actions proposed in National Elephant Conservation Action Plan (NECAP).

Conclusion: This study provides very first evaluation on sex ratio and determination of age structure among Asian elephants in the TNNP by using genetic information from faecal samples. We successfully assess population sex structure of wild and free ranging elephants with noninvasive DNA samples together with reliable molecular sexing protocols that target $\mathrm{X}$ and $\mathrm{Y}$ chromosomespecific markers. The combination of field and molecular ecology protocols in this study provided reliable information on the sex ratio pattern and age structure of free roaming elephant individuals in TNNP. Size of intact elephant bolus provides hidden information on age category of these large mammals and provides wildlife researchers and managers with strong baseline data for monitoring and conservation management strategies of this species. This outcome will play an important role in law enforcement patrolling by DWNP in TNNP by providing supporting details for cases involving elephant poaching in the wild.

Acknowledgements: We are grateful to YBhg. Dato' Abdul Kadir bin Abu Hashim, Director General of the DWNP; Mr. Rahmat bin Topani, the Director of Conservation Exsitu Division; Dr. Pazil bin Abdul Patah, the Director of Conservation Biodiversity Division; Mr. Salman bin Hj. Saaban, Director of Enforcement Division and Dr. Jeffrine Rovie Ryan Japning, Head of Research Section and finally Mr. Muhammad Munir Idris for their support during conducting this research activity. We are very thankful for Elephant Rescue Unit team for collecting precious samples with high risk in Taman Negara National Parks. We also expressed our gratitude to Department of Biological Sciences and Biotechnology, Faculty of Science and Technology, Universiti Kebangsaan Malaysia (UKM) for providing great assistance. This study was funded by Fundamental Research Grant Scheme (FRGS/1/2016/STG05/NRE/1) and Grant UKM-ST-2016-012.

\section{REFERENCES}

Abdul-Latiff, M.A.B., N.R. Aifat, S. Yaakop, and B.M. Md-Zain (2017). A noninvasive molecular approach: exploiting species-locus-specific PCR primers in defeating numts and DNA crosscontamination of cercopithecidae The J. Anim. and Plant Sciences 27: 1015-1023.

Abdul-Latiff, M.A.B., H. Baharuddin, P. Abdul-Patah, and B.M. Md-Zain (2019). Is Malaysia's banded langur, Presbytis femoralis femoralis, actually Presbytis neglectus neglectus? Taxonomic revision with new insights on the radiation history of the Presbytis species group in Southeast Asia. Primates 60 (1): 63-79.

Aifat, N.R., S. Yaakop, and B.M. Md-Zain (2016). Optimization of partial Cyt $b$ gene sequence from selected ancient Presbytis museum skin specimens. Malaysian Applied Biology 45: 9396.

Ahlering, M.A., S. Hedges, A. Johnson, M. Tyson, S.G. Schuttler, and L.S. Eggert (2011a). Genetic diversity, social structure and conservation value of the elephants of the Nakai Plateau, Lao PDR, based on non-invasive sampling. Conservation Genetics 12: 413-422.

Ahlering, M.A., F. Hailer, A. Johnson, M.T. Roberts, and C. Foley (2011b). A simple and accurate method to sex savannah, forest and Asian elephants using noninvasive sampling techniques. Molecular Ecology 11: 831-834.

Asian Elephant Conservation Act of 1997 (1997). Available:

https://www.fws.gov/international/pdf/multinati onal-species-conservation-act-asian-elephant.pdf

Borchers, D.L., S.T. Buckland, and W. Zucchini (2002). Estimating Animal Abundance: Closed Populations. Statistics for Biology and Health.

Chakraborty, S., D. Boominathan, A.A. Desai, and T.N.C. Vidya (2014). Using genetic analysis to estimate population size, sex ratio, social organization in an Asian elephant population in conflict with humans in Alur, Southern India. Conservation Genetics https://doi.org/10.1007/s10592-014-0587-y. 
Choudhury, A., D.K. Lahiri Choudhury, A. Desai, J.W. Duckworth, P.S. Easa, A.J.T. Johnsingh, P. Fernando, S. Hedges, M. Gunawardena, F. Kurt, and U. Karanth (2008). Elephas maximus. The IUCN Red List of Threatened Species. IUCN SSC Asian Elephant Specialist Group (2008).

CITES (2017). Convention On International Trade In Endangered Species Of Wild Fauna And Flora Appendices I, II and III. Available: https://www.cites.org/sites/default/files/eng/app/ 2017/E-Appendices-2017-10-04.pdf.

DWNP (2013). Department of Wildlife and National Parks Peninsular Malaysia, 2013. National Elephant Conservation Action Plan: Blueprint to Save Malaysian Elephants. Kuala Lumpur: Department of Wildlife and National Parks Peninsular Malaysia.

DWNP Annual Report (2015). Available at: http://www.wildlife.gov.my

Easa, P.S. and M. Balakrishnan (1995). The population density and structure of Asian elephants in Parambikulam Wildlife Sanctuary, Kerala, India. Bombay Nat. Hist. Soc. 92: 225-229.

Elliza, M.N., M.N. Shukor, N. Othman, and B.M. MdZain (2015). Haplotype distribution among endangered Asian elephants (Elephas maximus) in Peninsular Malaysia. Malaysian Applied Biology 44: 129-135.

IUCN (2017). The IUCN red list of threatened species. In: Version 2017-1, (<www.iucnredlist.org $>$. Downloaded on 24 June 2017).

FTA Technology (2011). Available at: https://www.gelifesciences.com

Fernando, P. and P. Leimgruber (2011). In The Ecology and Conservation of Seasonally Dry Forests in Asia: Asian elephants and dry forests. Smithsonian Institution Scholarly 151-163.

Fernando, P., T.N.C. Vidya, J. Payne, M. Stuewe, G. Davison, R.J. Alfred, P. Andau, E. Bosi, A. Kilbourn, and D.J. Melnick (2003). DNA analysis indicates that Asian elephants are native to Borneo and are therefore a high priority for conservation. PLoS Biol. 1: 110-115.

Hedges, S., A. Johnson, M. Ahlering, M. Tyson, and L.S. Eggert (2013). Accuracy, precision, and costeffectiveness of conventional dung density and fecal DNA based survey methods to estimate Asian elephant (Elephas maximus) population size and structure. Biological Conservation 159: 101-108.

Hedges, S. (2012). Estimating elephant population density and abundance from dung pile density: theoretical concepts. In: Hedges, S (Ed). Monitoring elephants and Assessing Threats: a Manual for researchers, managers and conservationists. University Press (India) Private Limited, Himayatnagar, India.

Hedges, S. and D. Lawson (2006). Dung survey standards for the MIKE Programme. CITES Mike Programme, Central Coordinating Unit, PO Box 68200 Nairobi, Kenya.

Katugaha, H., M. de Silva, and C. Santiapillai (1999). A long-term study on the dynamics of the elephant (Elephas maximus) population in Ruhuna National Park, Sri Lanka. Biol. Conserv. 89: 5159.

Kongrit, C. and C. Siripunkaw (2017). Determination of age and construction of population age structure of wild Asian elephants based on dung bolus circumference. Thai. J. Vet. Med. 47(2): 145153.

Kumara, H.N., S. Rathnakumar, and M.A. Kumar (2012). Estimating Asian elephant, Elephas maximus, density through distance sampling in the tropical forests of Biligiri Rangaswamy Temple Tiger Reserve, India. Trop. Conserv. Sci. 5: 163-172.

Life Technologies Corporation (2012). GeneMapper ${ }^{\circledR}$ Software 5, Availabel at : https://www.lifetechnologies.com.

Magintan, D., M.N. Shukor, T. Lihan, A.C. Arceiz, S. Salman, M.H. Shahril, and M.N. Ahmad (2016). AIP Conference Proceedings 1784, 060006. https://doi:10.1063/1.4966844

Md-Zain, B.M., S.N.A. Abid-Kamal, N.R. Aifat, M.A.B. Abdul-Latiff, A. Mohd-Hashim, A. Ampeng, S. Yaakop, and A. Samat (2018). Molecular identification of shark fins in Malaysian Borneo's local markets. Biodiversitas 19: 10351043.

Md-Zain, B.M., S.J. Lee, M. Lakim, A. Ampeng, and M.C. Mahani (2010). Phylogenetic position of Tarsius bancanus based on partial Cytochrome $b$ DNA sequences. J. Biological Sciences 10(4): 348-354.

Moßbrucker, A.M., I. Apriyana, J.R. Fickel, M.A. Imron, S. Pudyatmoko, Sumardi, and H. Suryadi (2015). non-invasive genotyping of Sumatran elephants: Implications for conservation. Tropical Conservation Science 8(3): 745-759. https://doi.org/10.1177/194008291500800312

Nagulendran, K., R. Padfield, S.A. Aziz, A.A. Amir, A.R. Rahman, J. Wadey, and A.C. Arceiz (2016). A multi-stakeholder strategy to identify conservation priorities in Peninsular Malaysia. Cogent Environmental Science 2: 1-19.

Neupane, D., Y. Kwon, T.S. Risch, A.C. Williams, and R.L. Johnson (2019). Habitat use by Asian elephants: Context matters, Global Ecology and Conservation. doi: https://doi.org/10.1016/j. gecco.2019.e00570.

Okello, J.B.A., C. Masembe, H.B. Rasmussen, G. 
Wittenmyer, P. Omondi, O. Kahindi, V.B. Muwanika, P. Arctander, I. Douglas-Hamilton, S. Nyakaana, and H.R. Siegismund (2008). Population genetic structure of savannah elephants in Kenya: conservation and management implications. J. Heredity 99: 443452.

Promega products (2016). Available at: https://worldwide.promega.com//media/files/res ources/protocols/product-information sheets/g/pcr-master-mix-protocol.pdf?la=en

Ripple, W.J., G. Chapron, J.V. López-Bao, S.M. Durant, D.W. Macdonald, P.A. Lindsey, and L. Zhang (2017). Conserving the world's megafauna and biodiversity: the fierce urgency of now. Bioscience 67: 197-200.

Salman, S., O. Nasharuddin, Y. Nawayai, M.N. Burhanuddin, A. Zafir and A. Campos-Arceiz (2011). Current status of Asian elephants in Peninsular Malaysia. Gajah 35: 67-75.

Sripiboon, S. (2013). Elephant conservation genetics: Elephant Research and Education Center. Available at http://www.asianelephantresearch. com/about-elephant-conservation-genetics.php

Sukumar, R. (2003). The living elephants: evolutionary ecology, behavior, and conservation. New York: Oxford University Press.

Thermo Fisher Scientific (2010). Available at http://tools.thermofisher.com/content/sfs/manual s/nd-1000-v3.8-users-manual-8\%205x11.pdf
Tyson, M., S. Hedges, and A.F. Sitompul (2002). WCSIndonesia Sumatran elephant project: Six-month report January-June, 2002. Wildlife Conservation Society, Bronx, NY, USA.

Vidya, T.N.C., P. Fernando, D.J. Melnick, and R. Sukumar (2005). Population differentiation within and among Asian elephant (Elephas maximus) populations in southern India. Heredity 94: 71-80.

Vidya, T.N.C., V.R. Kumar, C. Arivazhagan, and R. Sukumar (2003). Application of molecular sexing to free-ranging Asian elephant (Elephas maximus) populaitons in Southern India. Current Science 85(7): 1074-1077.

Wadey, J., Beyer, H.L., Saaban, S., Othman, N., Leimgruber, P. and Campos-Arceiz, A (2018). Why did the elephant cross the road? The complex response of wild elephants to a major road in Peninsular Malaysia. Biological Conservation 218: 91-98.

Williams, A.C., A.J.T. Johnsingh, and P.R. Krausman (2007). Population estimation and demography of the Rajaji National Park elephants, NorthWest India. J. Bombay Nat. Hist. Soc. 104: 145 152.

Zainudin, R., M.N. Shukor, A. Norhayati, B.M. MdZain, and A.R. Mustafa (2010). Genetic structure of Hylarana erythraea (Amphibia: Anura: Ranidae) from Malaysia. Zoological Studies 49(5): 688-702. 